\title{
A Critical Assessment of Green Ammonia Production and Ammonia Production Technologies
}

\author{
A. O. Gezerman* \\ Toros Agri \& Industry, Research \& Development Center, \\ Karaduvar M. 132. C. No: 3,33 020, Mersin, Turkey
}

https://doi.org/10.15255/KUI.2021.013

\begin{abstract}
Greenhouse gas emissions in industrial raw material production significantly reduce the global air quality, which directly affects the quality of life. In order to reduce greenhouse gas emissions, it is seen that country administrations encourage the development of industrial production processes according to regulations and laws. Currently, ammonia synthesis is the industrial process that emits the highest amount of carbon dioxide. An enormous $1.6 \mathrm{t}$ of carbon dioxide is released for every tonne of produced ammonia. In this study, in order to reduce the carbon emissions during ammonia production, an evaluation of ammonia production processes and technology is made and sustainability is discussed.
\end{abstract}

\section{Keywords}

Green ammonia, blue ammonia, brown ammonia, hydrogen, carbon emission

\section{Introduction}

Ammonia has had a profound global impact since the discovery of ammonia synthesis from nitrogen and hydrogen by Haber-Bosch in Germany at the beginning of the $20^{\text {th }}$ century. In order to use the ammonia as a fuel in the near future and to reduce greenhouse gas emissions during ammonia production, researchers are intensively working on the improvement of existing ammonia production processes as well as on alternative ammonia production processes. ${ }^{1}$ It has been reported that catalysts such as ruthenium impact the combustion process of ammonia and energy production by affecting the amount and type of exhaust gas released during these processes. ${ }^{2}$ Due to the fact that ammonia contains hydrogen bonds and these hydrogen bonds contain high energy, various studies have been carried out on its burning. Each substance used as a fuel, such as fossil fuels, has a certain flame-forming capacity. The flame formation capacity determines the flame length of the fuel at the end of time. The flame length resulting from the combustion of ammonia is shorter than that of natural gas or other fossil fuels. ${ }^{3}$ Various studies have been conducted in order to convert natural resources into ammonia and to use them as fuel. ${ }^{4}$ Besides being used as a raw material for power generation, ammonia can also be used as an industrial refrigerant. It has been reported that the use of ammonia as a refrigerant in the condensation stages of a power generation process causes an increase in the power generation capacity. ${ }^{5}$ Considering ammonia as a raw material for energy production has led to the development of various production processes. Oxidation of aluminium nitride ${ }^{6}$ and solid oxide fuel cell ${ }^{7}$ are some of the energy production processes from ammonia. ${ }^{7}$ Ammonia production from biomass has been studied as an alternative source to ammonia production from fossil fuels, but due to the very limited

*Ahmet Ozan Gezerman, PhD

Email: ozan.gezerman@toros.com.tr, ahmet_ozan@yahoo.com biomass source for ammonia production on an industrial scale, it was not found to be preferable in ammonia production. ${ }^{8}$ To reduce greenhouse gas emissions, the current research is focused on ammonia usage as a fuel in transportation and other sectors of industries. This research recognises the necessity of an ammonia production process, which will not only be able to produce ammonia without subsequent $\mathrm{CO}_{2}$ emissions, but will also be economically competitive with respect to the current ammonia production processes, which employ fossil fuels. The main demerit of the current ammonia production using fossil fuels is high $\mathrm{CO}_{2}$ emissions, which also results in the end usage (as fuel and in fertilization) transfer of $\mathrm{CO}_{2}$ emissions. ${ }^{9}$ However, the increase in the amount of $\mathrm{NO}_{x}$ is a problem that should be minimised due to its effect on global warming. On the other hand, carbon dioxide production occurring in the carbon capture stage in the ammonia process with low carbon emission has been reported in various studies. ${ }^{10}$ In such a study, $\mathrm{CO}_{2}$ capture was achieved with $90 \%$ capacity of efficiency as a carbon capture potential. ${ }^{11}$ In studies conducted on the addition of organic components to increase the combustion potential of ammonia, it was concluded that the combustion property of the used hydrocarbon had increased depending on the carbon chain length. ${ }^{12}$ In another research study on the oxidation of ammonia, the effect of the mixture of oxygen and argon on the combustion process was examined and pyrolysis tests were carried out by examining the combustion behaviour of the mixture. It has been reported in the analysis studies that this oxygen-argon mixture failed to show stable behaviour for the combustion reaction of ammonia. ${ }^{13}$

When examining the chemical structure of waste gases in the combustion environment by mixing with high-calorie fuels in order to monitor the combustion reactions of ammonia, mixing with fuels with low calorific value for low $\mathrm{N}_{2} \mathrm{O}$ emission has been determined. ${ }^{14}$ In another research study in which ammonia can be used as fuel, a gas turbine 
was used and a research study was conducted on increasing the performance thereof. In this study, the performance obtained by adding certain proportions of hydroxy gas to ammonia fuel was evaluated. ${ }^{15}$

In another research study on the oxidation of ammonia, a jet mixed flow reactor was used and the combustion performance of ammonia at different temperatures was investigated. It has been reported that the reactivity of ammonia varies depending on the temperature. ${ }^{16}$ In order to minimise the amount of $\mathrm{NO}_{x}$ gas released during the combustion of ammonia, it is aimed to increase the thermal efficiency by feeding the unburned part of hydrogen to the heat recovery generator. Thus, while maintaining the thermal efficiency of ammonia during combustion, it was determined that the amount of $\mathrm{NO}_{x}$ emission decreased. ${ }^{17}$ In another study on increasing the burning capacity of ammonia, two different test methods were developed. In one method, the increase of burning capacity of ammonia with the addition of a conventional hydrocarbon was studied, and in the other comparison method, the increase in the burning capacity of ammonia by using an oxidising catalyst in the combustion chamber was investigated. ${ }^{18}$

In another research study on the combustion characteristics and energy capacity of ammonia, the combustion characteristic of the coal-ammonia mixture was investigated. Coal-ammonia mixture has been found to have lower carbon emission than crude coal. ${ }^{19}$

However, for the production of hydrogen, which is used as a raw material in ammonia synthesis, various production scenarios have been developed for the production of blue ammonia with lower carbon dioxide emissions, while the focus is on green ammonia production where no carbon dioxide emission occurs. ${ }^{20}$ In China, where ammonia is mostly produced as a raw material, alternative processes such as Solid Oxide Electrolysis Cell are being studied in green ammonia production in order to reduce the carbon emissions. ${ }^{21}$ Achieving high purity and recovery in the pressurised adsorption process developed for the production and use of ammonia as a fuel is an important study reported on an industrial scale. ${ }^{22}$

Since ammonia is the most important nitrogen source for the entire fertiliser production industry, it is produced synthetically to meet this demand. Due to the air pollution problem caused by the Haber-Bosch process, which is accepted as the traditional method in ammonia production, causing high carbon dioxide emission during ammonia production, it has become necessary to develop various processes to reduce carbon dioxide emissions. ${ }^{23}$ Today, various carbon removal techniques, known as decarbonisation, can be integrated into ammonia production processes in order to reduce the carbon dioxide emissions in synthetic ammonia production processes. Ammonia produced by a decarbonisation technique in this way is known as blue ammonia. ${ }^{20}$ The blue ammonia production process is one of the important solutions proposed to reduce the carbon dioxide emissions, as the Haber-Bosch production process requires high investment costs. ${ }^{24}$ The Carbon Capture Use and Storage (CCUS) cost for blue ammonia production is 10 EUR per tonne of ammonia production, while the Capital Expenditures (CAPEX) cost for the same is around 100 EUR. In contrast, there is no CCUS cost for one tonne of ammonia produced by the Haber-Bosch process, while the CAPEX cost is around 70 EUR for one tonne of ammonia compared to the blue ammonia production. ${ }^{20}$ The operating cost of green ammonia production processes, also known as the ammonia production process with no carbon dioxide emissions, is around $\$ 500$ per tonne, which is still far from acceptable for large-scale ammonia production $\left(>50 \mathrm{th}^{-1}\right)$. Therefore, the use of decarbonisation processes, such as the HaberBosch process, seems more attractive to manufacturers for ammonia production. ${ }^{5,26}$ Various production methods have been developed for green ammonia production processes in which no carbon dioxide emission occurs. These can be listed as liquid electrolyte-based systems, molten saltbased electrolyte systems, composite membrane-based systems, ceramic/inorganic proton conducting solid electrolyte-based systems, polymer membrane-based systems, and $\mathrm{O}_{2}$-conducting membrane materials systems. ${ }^{27} \mathrm{How}$ ever, as mentioned, these technologies are yet to be commercialised, as ammonia is not produced at a scale to meet today's ammonia need. ${ }^{28}$

In this evaluation study, alternative hydrogen production methods were evaluated in order to prevent the carbon emissions during the production of hydrogen used as an intermediate input in the Haber-Bosch process for ammonia production. However, it is aimed at guiding researchers for the development of industrial processes studied for ammonia production. In addition to a comprehensive comparison of energy consumption and costs for ammonia production processes, it is aimed at guiding and giving ideas for new research by evaluating the situation regarding the production process and storage of ammonia.

\subsection{Ammonia production technologies and chemical characterisation}

Ammonia can be classified according to the amount of carbon it generates. In this respect, according to the carbon gas emission released during hydrogen production, which is one of the main stages of ammonia production, its production can be classified in three ways: brown ammonia, blue ammonia, and green ammonia.

Brown ammonia production is based on the use of a fossil fuel as a raw material for hydrogen production, with an emission of approximately $2.86 \mathrm{t}$ of carbon dioxide per $1 \mathrm{t}$ of ammonia ${ }^{20}$ during production (Fig. 1).

Brown ammonia, which can be described as an example of today's ammonia production process, is mainly based on Haber-Bosch process. During this process, the process of ammonia production occurs as a catalytic reaction of hydrogen produced as a starting product and nitrogen, which is separated from the air by a separation unit process. Generally, the brown ammonia process requires enormous energy consumption, such as $8 \mathrm{MWh} \mathrm{t}^{-1} .^{20}$

However, most of the energy during the process is consumed for hydrogen gas production, and $90 \%$ of the carbon emission in the process is due to hydrogen production. Hydrogen gas is produced by steam reforming of 


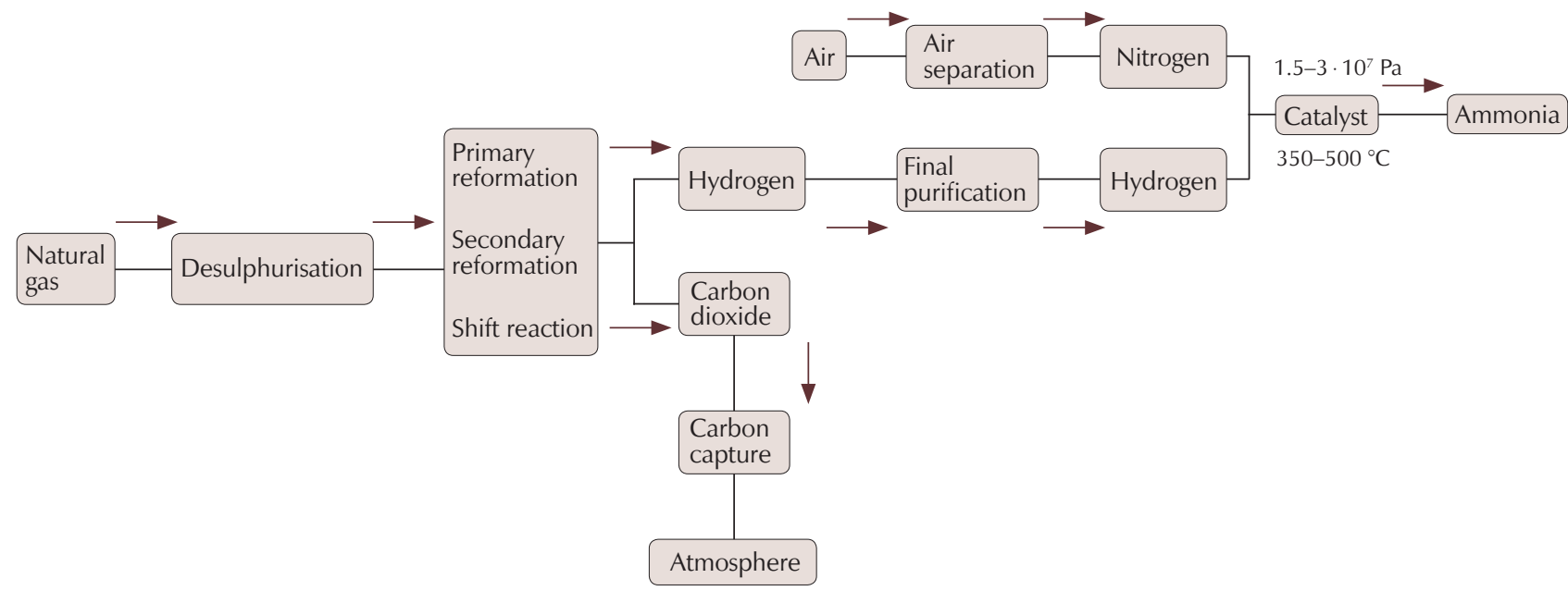

Fig. 1 - Brown ammonia production and process parameters

methane. In ammonia production, the amount of carbon dioxide (2.5-3.8 t) released as a result of reforming other fossil fuels such as coal with steam is much higher than that of natural gas $(1.6 \mathrm{t}) .^{20}$ Therefore, natural gas is used for the production of hydrogen as an intermediate input during the production of ammonia. Ammonia is basically obtained by reacting the nitrogen (separated from the air by means of a separation unit) with hydrogen, which is separated from the natural gas or coal using an iron-based catalyst.

Coal, fuel oil, and naphtha can be used as raw materials in ammonia production. Fossil fuels such as natural gas or coal, due to their high carbon content, cause the formation of large amounts of carbon dioxide during hydrogen production. When natural gas is used for ammonia production, $1.6 \mathrm{t}$ of carbon dioxide is emitted per $1 \mathrm{t}$ of ammonia. ${ }^{21}$ Nitrogen, as one of the reactants in ammonia synthesis reaction, can be obtained from the air via some autothermal conversion mechanisms, such as secondary reforming. While employing such approaches, the synthesis gas from the primary reforming process is combined with the air in the secondary reforming reactor at temperature of around $1000{ }^{\circ} \mathrm{C}$ and pressure of around $3039750 \mathrm{~Pa} .{ }^{29}$ There have been several future scenarios discussed for low carbon ammonia production. In present-day ammonia production, the two most important developments are the blue hydrogen production process, which uses the carbon capture technique developed to reduce the high amount of (500 million $\mathrm{t}^{-1}$ ) carbon dioxide emission, and the green hydrogen production technique, in which no carbon source is used for hydrogen production. Since $\mathrm{H}_{2}$ is produced by electrolysis of water, there are no carbon dioxide emissions. ${ }^{20}$

The blue hydrogen production process aims to ensure extremely low carbon emissions during the production process, which are at least $90 \%$ lower compared to the emissions during the brown ammonia production process. ${ }^{20}$ This low concentration is made possible by the application of a carbon capture process after the hydrogen production process. Fig. 2 shows the steps of such a hydrogen generation process. In order to produce blue hydrogen and subsequently blue ammonia by the Haber-Bosch process,

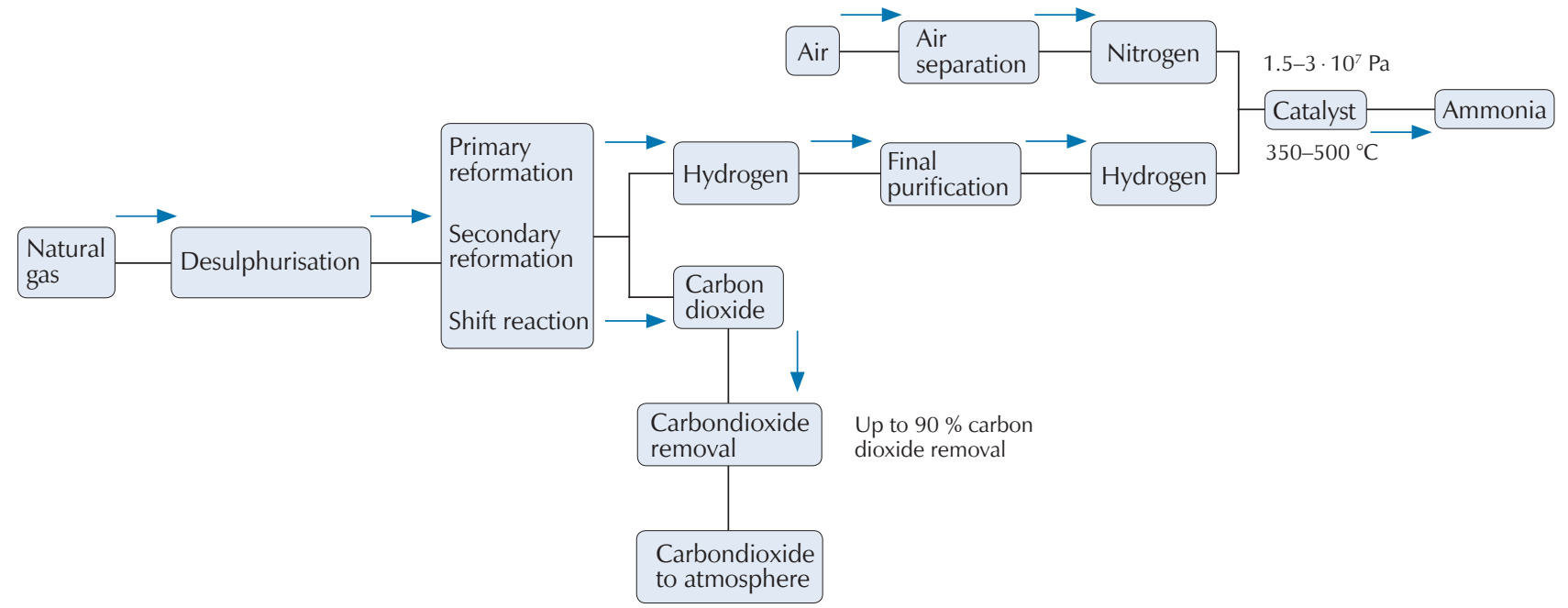

Fig. 2 - Blue ammonia production process steps 
different decarbonisation techniques can be applied. With such techniques, an intermediate solution to the final decarbonisation of ammonia production can be achieved.

For blue ammonia production, the addition of a carbon dioxide removal unit to the Haber-Bosch process provides $90 \%$ carbon emission removal, as well as the complete elimination of carbon emissions with green ammonia production, which can be shown as significant technological advances in the development of hydrogen production. ${ }^{20}$

In the green ammonia production process, sustainable energy is produced by using renewable resources such as water, solar energy, and air. Commercial anhydrous ammonia has a standard purity of $99.9 \%$. Various methods such as decarbonisation have been developed to reduce carbon dioxide emissions when hydrogen and ammonia are produced. The amount of carbon dioxide released during the production of hydrogen, and, as a result, the amount of ammonia released, may differ depending on the use of natural gas or other fossil fuels as raw materials. ${ }^{20}$ As mentioned, hydrogen production can be carried out in different ways. For example, there are green ammonia production processes that do not use fossil fuels such as coal or natural gas, only hydrogen gas is obtained by electrolysis of water, and as a result contain no carbon compounds. Wind and solar energy are used to produce the energy needed for green ammonia production. Since wind and solar energy contain no carbon source, there is no carbon emission during the green ammonia production process. Nitrogen gas, another raw material of the ammonia production process, is provided by passing the air through a high-temperature membrane-based air separation unit.

\subsection{Green ammonia production and technology}

\subsubsection{Green ammonia production using green hydrogen by electrolysis of water}

The largest commercial production capacity in which hydrogen is produced by the water electrolysis method in order to be used as a raw material in the production of ammonia is $10 \mathrm{t} \mathrm{d}^{-1}$. It is not possible to provide such a production capacity with the Proton Exchange Membrane (PEM) method, which is used frequently for green ammonia production. Therefore, studies are underway to develop large-scale $\left(>10 \mathrm{t} \mathrm{d}^{-1}\right.$ ) green ammonia production methods. ${ }^{20}$ Table 1 shows energy consumption amounts and process efficiencies of various technologies using ammonia as an energy source..$^{20}$

The production of hydrogen gas, which is needed as a process input for ammonia production, forms the basis of the decarbonisation of all ammonia production processes. Since the electrical energy needed in the green ammonia production process is obtained by using renewable energy sources such as wind and solar energy, no carbon gas emissions can occur during green ammonia production.

Nitrogen is obtained directly from the air using a separation unit. The energy used by this air separation unit is $3 \%$ of the energy consumed by the entire process. ${ }^{20}$ Today, large-scale $\left(>50 \mathrm{th}^{-1}\right)$ ammonia production is carried out using coal and natural gas. A large amount of energy
Table 1 - Process efficiency and energy consumption cost when ammonia is used as an energy source

\begin{tabular}{l|c|c}
\hline Ammonia fuel technology & $\begin{array}{c}\text { Process } \\
\text { efficiency } / \%\end{array}$ & $\begin{array}{c}\text { Energy cost/ } \\
\$ / \mathrm{kW}\end{array}$ \\
\hline $\begin{array}{l}\text { Proton exchange } \\
\text { membrane fuel cell }\end{array}$ & 50 & 1.300 \\
\hline Alkaline fuel cell & 60 & 1.300 \\
\hline Solid oxide fuel cell & 65 & 760 \\
\hline Internal combustion engine & 40 & 1.000 \\
\hline Boilers and furnaces & 90 & 350 \\
\hline Combined cycle gas turbine & 60 & 750 \\
\hline
\end{tabular}

(8 MWh) per tonne of ammonia is needed to produce such ammonia. The biggest problem here is that electricity is more expensive than natural gas in most parts of the world, and this constitutes $85 \%$ of the process cost. ${ }^{20}$ However, another parameter that affects production costs during ammonia production is carbon capture technologies. Carbon capture technologies integrated into the system during ammonia production are the best solution available to reduce carbon dioxide emissions while increasing the investment costs of the process. ${ }^{20}$ In present times, with constantly changing energy costs, production of one ton of ammonia with the Haber-Bosch process, which is the traditional method of ammonia production, costs approximately 300 EUR, including energy costs. In contrast, the operating cost for one tonne of ammonia (green ammonia) using electrochemical methods is estimated to be around 1250 EUR, including energy consumption costs. ${ }^{20}$

In regions where renewable energy sources such as wind and solar are available, the cost of electricity has decreased significantly in the last 10 years. ${ }^{20}$ However, there are significant differences between the cost of hydrogen gas produced by electrolysis of water in regions where electricity generation is provided by renewable energy sources, and the cost of hydrogen gas production with steam reforming that includes carbon capture and storage systems in regions with the most efficient renewable power plant. Having the advantage of low electrical energy costs also allows the hydrogen to be transported on a large scale at an affordable cost. Fig. 3 shows the green ammonia production process as an alternative to blue ammonia production.

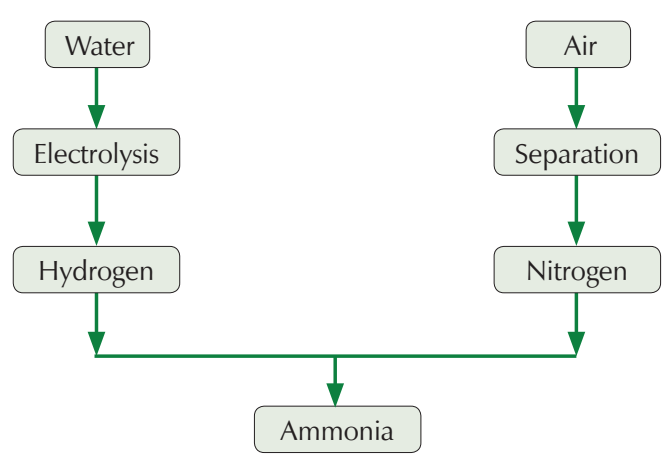

Fig. 3 -Green ammonia production process and process scheme 
The limiting parameter in green ammonia production is the energy consumption used for hydrogen gas production. Energy production from renewable energy sources, such as sun and wind, is important to avoid carbon dioxide emission. The fact that the energy needed by the ammonia plants is located close to the ammonia production facilities can contribute to the development of the ammonia production process. Therefore, it is essential that green ammonia production facilities are located in an area that makes the most of wind and solar energy.

\section{Discussion}

As the target in green ammonia production is to prevent carbon release in hydrogen gas production, which is one of the main components of ammonia production, all decarbonisation steps in possible hydrogen production processes are an infrastructure for green ammonia processes. During the use of ammonia as a fuel material, a significant amount of energy (5.2 $\mathrm{MWh}^{-1}$ ) is released due to the release of hydrogen in its content. Storing this energy is important for efficient use of energy. In systems where carbon emissions are sufficiently minimised, green ammonia is used as an energy source, the energy density of $3 \mathrm{kWh} \mathrm{I}^{-1}$ of ammonia, using ammonia as a fuel raw material can form the basis of clean energy production. Ammonia has been used as an important raw material in fertiliser industry until today, and causes a significant amount of greenhouse gas emission during its production. While various process forms are available to reduce carbon dioxide emissions, few have worked well for application in large-scale ammonia production. However, electrolysis of water for the decarbonisation process targeted for ammonia production is the focus of the studies due to zero emissions. In ammonia production, it is aimed to capture and store carbon gas on the basis of the decarbonisation process or to produce hydrogen gas by electrolysis of water without using a fossil fuel source. Decarbonisation is provided in two ways in current ammonia production. One of these is the production of hydrogen by capturing and storing carbon-derived gases in current ammonia production. Another decarbonisation method is the production of hydrogen by electrolysis of water through electrical energy. Since no fossil fuel source is used in the electrolysis method, no carbon gas emission occurs.

Greenhouse gas emissions do not only affect air quality, but also significantly reduce the diversity of bacteria in the soil. ${ }^{30}$ However, the prediction of using ammonia as an energy source other than for agricultural purposes, reveals the need to eliminate the ecological problems that may arise. It requires that ammonia be stored after production in order to be used as an energy source. Maintaining pressure $(1.7 \mathrm{MPa})$ and temperature $\left(<40{ }^{\circ} \mathrm{C}\right)$ conditions ${ }^{31}$ during the storage of ammonia is the most important step of the process, and this process is as costly as carbon dioxide removal technologies. Therefore, any possible leakage in ammonia storage systems will seriously damage the ecosystem where it is located.

Finding affordable and effective solutions for the production of ammonia with decarbonisation processes is vital in terms of clean energy production. In current ammonia production technologies, the decarbonisation process is a potential for green ammonia production and is important in minimising dependence on fossil fuels. Ammonia is used in refrigeration systems as an industrial refrigerant, as well as for fertiliser production, and it is a clean energy source for the near future. ${ }^{32}$ It has an increasing use, especially in applications in the food processing industry and large-scale air conditioning systems. ${ }^{32}$ Ammonia is also an important component in the production of additives used to reduce $\mathrm{NO}_{x}$ emissions in vehicles, and is included as an important process component in the textile, pharmaceutical, and explosive industries. ${ }^{33}$

The most important role of ammonia today is that it is a raw material for inorganic fertilisers that produce food for around half of the world's population. There is a global production of around 176 million tonnes of ammonia per year. Anhydrous ammonia is mainly produced by the Haber-Bosch process by producing hydrogen gas as a result of the steam treatment of natural gas, and then separating the nitrogen in the air with a separation process and reacting with the produced hydrogen gas. ${ }^{20}$ During the production of hydrogen gas for ammonia production, a large proportion of carbon gas is emitted. During ammonia production, although energy consumption constitutes a cost problem as much as carbon gas emission, it is known that approximately $1.8 \%$ of the electrical energy produced each year is consumed during ammonia production. Eighty percent of this energy is consumed during the synthesis of hydrogen gas from methane gas. ${ }^{34}$ During this process, approximately 500 million tons of carbon dioxide emission occurs, which constitutes $1.8 \%$ of the global scale carbon dioxide emission. ${ }^{35}$ Anhydrous ammonia synthesis is the industrial process that produced the most carbon dioxide emissions on the earth's surface. ${ }^{36}$ Along with the production of cement, steel, and ethylene, it is one of the four major industrial processes that are aimed at achieving zero carbon emissions by $2050 .{ }^{37}$ The use of ammonia as a future technology, as an energy carrier, and as a fuel providing zero carbon emission in this sense, is on the agenda. Along with the fossil fuels, it is a potential fuel and also chemical energy storage due to the energy released by the breakdown of the chemical bond in ammonia. Combustion of ammonia involves the breaking of bonds between nitrogen and hydrogen in the presence of oxygen. With oxygen present, ammonia provides energy by breaking the covalent bonds between its constituents, nitrogen and hydrogen, under the catalysis of ferric oxide-bismuth oxide-manganese dioxide at approximately $300{ }^{\circ} \mathrm{C} .{ }^{38}$ Therefore, the formation of nitrogen and water as a result of the combustion of ammonia with oxygen under the catalysis of iron-bismuth-manganese oxide at the mentioned temperature (maximum $300{ }^{\circ} \mathrm{C}$ ) is the usual result of a typical combustion process. ${ }^{38}$ The combustion properties of ammonia in the form of the combustion process are very similar to methane. ${ }^{39}$

By breaking four covalent carbon-hydrogen bonds in methane, an energy of $188,284.52 \mathrm{~kJ} \mathrm{~mol}^{-1}$ is released. ${ }^{40,41}$ Ammonia contains three covalent bonds between hydrogen and nitrogen atoms. When these bonds are broken, $46,025 \mathrm{~kJ} \mathrm{~mol}^{-1}$ energy is released. ${ }^{42}$ The biggest difference between carbon hydrogen bonds in methane and nitrogen 
hydrogen bonds in ammonia is the reaction products of carbon and nitrogen atoms in the centre. ${ }^{43}$ Because when methane is burned, carbon atoms produce carbon dioxide. When ammonia is burned with oxygen at $300{ }^{\circ} \mathrm{C}$ under the catalysis of iron-bismuth-manganese oxide, $\mathrm{NO}_{\mathrm{x}}$ is a by-product in addition to nitrogen and water. ${ }^{38}$

For bulk storage, it is compressed to $1 \mathrm{MPa}$ pressure or cooled to $-33^{\circ} \mathrm{C}$ and stored as such. In this case, the energy density of ammonia is $3 \mathrm{kWh}^{-1}$. Although this energy intensity is relatively smaller than a fossil fuel, it can be considered as an alternative to fossil fuels, as there is no carbon gas emission as a result of its combustion. Although the amount of $\mathrm{NO}_{x}$ released as a by-product during the combustion of ammonia is less than the amount of $\mathrm{CO}_{2}$ released during the combustion of methane, $\mathrm{NO}_{x}$ gases such as $\mathrm{NO}_{2}$ turn into nitrous acid $\left(\mathrm{HNO}_{2}\right)$ in the air and cannot remain suspended in the air due to being heavier than air, thus accumulating on the soil surface. ${ }^{44}$ Therefore, $\mathrm{NO}_{x}$ has no direct effect on air quality with this aspect. ${ }^{44}$ The hydrogen produced during the process as a raw material input during ammonia production must be able to be stored before ammonia production. In order for hydrogen to be stored, it is important to bring it to a temperature of $-253{ }^{\circ} \mathrm{C}$ in the pressure range of $35-71 \mathrm{MPa} .{ }^{20}$ However, hydrogen is denser, more energy-intensive, and more expensive to store than ammonia. In this case, considering anhydrous ammonia as an alternative energy source is a challenging process that needs to be developed with today's technology.

\subsection{Green ammonia production strategy and storage infrastructure}

Since it is used as a raw material in inorganic fertilisers, ammonia storage and transportation infrastructure has been developed. Large-scale maritime and transfer infrastructure is available for ammonia transfer. This port and sea transfer infrastructure can provide large-scale transfer of ammonia as an energy source and fuel. The largest ammonia storage facilities are located in ports where ammonia is produced and transferred, providing an important advantage in terms of ammonia production and consumption. ${ }^{1}$

Transferring the produced ammonia according to the consumption needs brings about various scaling studies. The amount of ammonia needed on a global scale for fertiliser production per year is at least 2 million tonnes, and at least twice this amount will be required for energy production. ${ }^{45}$

\subsection{Ecological considerations for ammonia production}

When ammonia is produced as an energy source or as a fertiliser raw material, the ecological damage caused by ammonia creates great problems. If anhydrous ammonia is discharged into the atmosphere through any leakage from the system where it is produced, it makes the soil in which it is found barren and due to its corrosive feature, it causes the soil to lose its agricultural properties. For this reason, the facilities where ammonia production will be carried out should be designed in a way to minimise the damage caused by the salivation of the soil under atmospheric conditions by ensuring the isolation of possible ammonia leaks. The fact that ammonia is a corrosive material increases the damage caused by ammonia compressed at high pressure. ${ }^{46}$ However, it can be easily detected by odour in low concentrations that cause permanent health problems. ${ }^{47}$

From an environmental point of view, ammonia is a hazardous chemical that creates air pollution and creates significant ecological problems when discharged into the atmosphere.

The use of nitrogenous compounds in various ways determines the degree of ammonia requirement. Plants cannot directly use nitrogen, which is present in the air. In this respect, plants can take nitrogen in the form of $\mathrm{NH}_{3}$ from the soil, not in the form of $\mathrm{N}_{2}$ from the air. ${ }^{48}$ Microorganisms in the soil convert nitrogen from the air into ammonia so that the plant can benefit from nitrogen. Therefore, synthetic ammonia is produced, which provides the nitrogen needed by plants. The nitrogen compounds required by the plant are applied to the soil by chemical fertilization method. Nitrogenous fertiliser production constitutes $80 \%$ of the fertiliser production. ${ }^{49}$ People can benefit from $17 \%$ of the nitrogen added to the plant as a result of chemical fertilization. The remaining part of the nitrogen contained in the fertiliser is removed in a form that the plant cannot benefit from by irrigation water and evaporation method from the soil.

When ammonia is removed from the soil by the fertilization method, it does not pose a threat to air pollution. ${ }^{50}$ However, it can turn into greenhouse gas form by transforming into nitrogen oxide compounds with the irrigation process. Nitrous oxide formation is an important parameter that directly affects the air quality problem. In addition to all these, in the use of ammonia as an energy source as a future technology, the release of ammonia as nitrogen gas during the combustion process is an important development in terms of minimising the emission problem.

\subsection{Research opportunities on ammonia production technologies}

Existing research focuses on the electrochemical methods, since no further development has been achieved on an industrial scale $\left(>10 \mathrm{td}^{-1}\right)$ other than electrochemical methods for ammonia synthesis, and zero emission has been achieved in the electrolysis method. It is essential that the electrical energy needed during electrolysis be produced with a zero carbon technology. In current ammonia production, electrolitical production of hydrogen gas can be carried out in small-scale production facilities $\left(10 \mathrm{t} \mathrm{d}^{-1}\right)$. However, in order to meet the amount of ammonia needed $\left(>100 \mathrm{th}^{-1}\right)$ for nitrogen fertiliser used in agricultural fields, it is important to increase the current ammonia production by electrolysis method. The most important constraint in today's technology for ammonia production process is the costs of the energy used. In order to minimise this problem, the required energy can be produced from renewable energy sources. 
In today's ammonia production technologies, process temperature and pressure values as well as the type of catalyst used for the reaction are important in terms of process optimization. Therefore, future technology scenarios for ammonia production are based on this type of optimization and ultimate success is achieved in small-scale production facilities. Although carbon gas emission is to some extent reduced by decarbonisation technology in an ammonia production facility, the use of renewable energy sources such as wind and solar energy for fulfilling energy needs is very important in terms of minimising carbon dioxide emissions. Optimization of the use of renewable energy sources for energy needs will contribute to the efficiency and continuity of the process. For this reason, the use of wind and solar energy in electrical energy production can be envisaged as an option.

By using the traditional method (Haber-Bosch) and the method of natural gas steam reforming, the cost of hydrogen production and decarbonisation during this process is less than the cost of electricity consumption. The difference that may occur in the types of catalysts used for ammonia production will bring some additional costs. Catalyst change is directly related to the ammonia production efficiency. For this reason, parameters such as pressure, temperature, and catalyst change to increase efficiency can be considered as factors that directly affect the cost of ammonia production.

In order to use the ammonia in energy production, fuel cell technologies are being studied. As stated in Table 1, proton exchange membrane fuel cell and alkaline fuel cell are some of the technologies in which ammonia is used as a fuel to produce energy. ${ }^{20}$ Table 1 also lists the energy production efficiencies of these power generation systems. It is clear that process efficiencies should improve the production process characteristics of ammonia compared to fossil fuels. However, during the production of ammonia produced with fossil fuels, $8 \mathrm{MWh}^{20}$ of energy is needed for $1 \mathrm{t}$ of ammonia, while ammonia produced by renewable resources requires energy in the range of 9-15 $\mathrm{MWh} \mathrm{t}^{-1} \cdot{ }^{51}$

Choosing the appropriate catalyst and process parameters as future technologies for ammonia production will significantly affect the amount of energy consumption and carbon emission. With the latest technology, the emission problem has been reduced to a certain level, an example of which is the blue ammonia process, which uses natural gas for ammonia production, and during which 1.6 tonnes of $\mathrm{CO}_{2}$ is emitted per tonne of ammonia production. This is paving the way for the development of new technologies, which may eliminate carbon gas emissions. However, the liquefaction of hydrogen gas as a process input during ammonia production and the improvement of the process conditions to reduce the system pressure provided by the stepped cylinders can be considered as the focal point of a research that needs to be studied for ammonia production, since it directly affects the amount of energy consumed.

In the anhydrous ammonia production process, storage of ammonia is as important as its production. Since ammonia has a low boiling point $\left(101325 \mathrm{~Pa},-33^{\circ} \mathrm{C}\right)$ and it is a corrosive and cryogenic chemical, copper and zinc alloys should not be used in ammonia storage systems ${ }^{52}$ and its isolation from the environment should be provided with materials with low heat conductivity coefficient such as glass wool.

\section{Conclusion}

In this study, the dependence on natural resources during the production of blue and green ammonia as an alternative to the production of ammonia as a future fuel, and minimising the carbon emission in agricultural fields is analysed and aimed at improving air quality and guiding future research to meet ammonia consumption in agricultural fields.

In addition to the Haber-Bosch process, where large-scale ammonia production is carried out today, there are various methods for the production of green ammonia in which no carbon gas emission occurs, but are still in their basic research stages. Ammonia is produced naturally by bacteria that contain the enzyme catalyst called nitrogenase in nature. This process takes place at room temperature and atmospheric pressure. This biologically occurring ammonia production process is a good example of the green ammonia production process. Therefore, future technologies for green ammonia production cannot be realised based on the biological process mentioned. However, ammonia production on an industrial scale can be developed on the same basis. In electrochemical production technology, water is electrolyzed using electric current and the resulting hydrogen gas is reacted with nitrogen in the air to produce anhydrous ammonia, which is called green ammonia and emits no carbon gas. The most important in this production process is that there is no separate hydrogen production process step. The most important advantage of such a production process is that no carbon gas is released while hydrogen gas is formed. Because, in today's hydrogen production technologies, fossil fuels used in the process of commissioning the process emit a large amount of carbon gas, which is the most important disadvantage of the relevant process. Green ammonia production in this way seems possible under laboratory conditions today, but it has been produced in pilot-scale low-capacity facilities. For the mentioned electrolysis method, the development of the possible electrolyte system to increase the hydrogen gas production capacity, and the selection of the appropriate catalyst can be considered as the future technology for such ammonia production. In contemporary industry, in addition to the use of ammonia as a fertiliser, development studies are continuing to use it as a fuel, which releases no carbon. Ammonia is an important alternative to fossil fuels because of its nitrogen and hydrogen bonds and its energy density potential $\left(3 \mathrm{kWh} \mathrm{L}^{-1}\right)$. However, the combustion reaction of ammonia in a combustion unit does not differ significantly from the combustion processes of fossil fuels. Thus, it is predicted that it will create no significant investment cost for ammonia producers. 


\section{ACKNOWLEDGEMENTS}

Ahmet Ozan Gezerman would like to thank Abdullah Emre Yüzbaşıoğlu and Ali Hikmet Tatarhan for their technical support during the preparation of this study.

\section{Literatura \\ References}

1. D. R. MacFarlane, P. V. Cherepanov, J. Choi, B. H. Suryanto, R. Y. Hodgetts, J. M. Bakker, A. N. Simonov, A roadmap to the ammonia economy, Joule 4 (2020) 1186-1205, doi: https://doi.org/10.1016/j.joule.2020.04.004.

2. W. Wang, J. M. Herreros, A. Tsolakis, A. P. York, Ammonia as hydrogen carrier for transportation; investigation of the ammonia exhaust gas fuel reforming, Int. J. Hydrog. Energy 38 (2013) 9907-9917, doi: https://doi.org/10.1016/j. ijhydene.2013.05.144.

3. A. Hayakawa, T. Goto, R. Mimoto, Y. Arakawa, T. Kudo, H. Kobayashi, Laminar burning velocity and Markstein length of ammonia/air premixed flames at various pressures, Fuel 159 (2015) 98-106, doi: https://doi.org/10.1016/j. fuel.2015.06.070.

4. A. T. Wijayanta, M. Aziz, Ammonia production from algae via integrated hydrothermal gasification, chemical looping, $\mathrm{N}_{2}$ production, and $\mathrm{NH}_{3}$ synthesis, Energy 174 (2019) 331-338, doi: https://doi.org/10.1016/j.energy.2019.02.190.

5. C. Zamfirescu, I. Dincer, Ammonia as a green fuel and hydrogen source for vehicular applications, Fuel Process. Technol. 90 (2009) 729-737, doi: https://doi.org/10.1016/j. fuproc.2009.02.004.

6. F. B. Juangsa, M. Aziz, Integrated system of thermochemical cycle of ammonia, nitrogen production, and power generation, Int. J. Hydrog. Energy 44 (2019) 17525-17534, doi: https://doi.org/10.1016/j.ijhydene.2019.05.110.

7. A. Afif, N. Radenahmad, Q. Cheok, S. Shams, J. H. Kim, A. K. Azad, Ammonia-fed fuel cells: a comprehensive review, Renew. Sustain. Energy Rev. 60 (2019) 822-835, doi: https:// doi.org/10.1016/j.rser.2016.01.120.

8. P. Arora, A. F. Hoadley, S. M. Mahajani, A. Ganesh, Smallscale ammonia production from biomass: a techno-enviro-economic perspective, Ind. Eng. Chem. Res. 55 (2016) 6422-6434, doi: https://doi.org/10.1021/acs.iecr.5b04937.

9. H. Kobayashi, A. Hayakawa, K. K. A. Somarathne, E. C. Okafor, Science and technology of ammonia combustion, Proc. Combust. Inst. 37 (2009) 109-133, doi: https://doi. org/10.1016/j.proci.2018.09.029.

10. H. A. Haugen, N. H. Eldrup, A. M. Fatnes, E. Leren, Commercial capture and transport of $\mathrm{CO}_{2}$ from production of ammonia, Energy Proced. 114 (2017) 6133-6140, doi: https://doi. org/10.1016/j.egypro.2017.03.1750.

11. K. Han, C. K. Ahn, M. S. Lee, Performance of an ammonia-based $\mathrm{CO}_{2}$ capture pilot facility in iron and steel industry, Int. J. Greenh. Gas Con. 27 (2014) 239-246, doi: https://doi. org/10.1016/j.ijggc.2014.05.014.

12. M. C. Rehbein, C. Meier, P. Eilts, S. Scholl, Mixtures of ammonia and organic solvents as alternative fuel for internal combustion engines, Energy Fuels 33 (2019) 10331-10342, doi: https://doi.org/10.1021/acs.energyfuels.9b01450.

13. M. V. Manna, P. Sabia, R. Ragucci, M. Joannon, Oxidation and pyrolysis of ammonia mixtures in model reactors, Fuel 264 (2020) 116768, doi: https://doi.org/10.1016/j. fuel.2019.116768.

14. M. Li, H. Tian, Z. Wei, Q. Zhang, B. Shen, Ammonia and ni- trous oxide emissions of a stoichiometric natural gas engine operating with high caloric value and low caloric value fuels, Fuel 285 (2021) 119166, doi: https://doi.org/10.1016/j. fuel.2020.119166.

15. R. Kenanoğ/u, E. Baltacioğ/u, An experimental investigation on hydroxy $(\mathrm{HHO})$ enriched ammonia as alternative fuel in gas turbine, Int. J. Hydrog. Energy 46 (2021) 29638-29648, doi: https://doi.org/10.1016/j.ijhydene.2020.11.189.

16. P. Sabia, M. V. Manna, A. Cavaliere, R. Ragucci, M. Joannon, Ammonia oxidation features in a Jet Stirred Flow Reactor. The role of $\mathrm{NH}_{2}$ chemistry, Fuel 276 (2020) 118054, doi: https://doi.org/10.1016/j.fuel.2020.118054.

17. M. Keller, M. Koshi, J. Otomo, H. Iwasaki, T. Mitsumori, K. Yamada, Thermodynamic evaluation of an ammonia-fueled combined-cycle gas turbine process operated under fuel-rich conditions, Energy 194 (2020) 116894, doi: https:// doi.org/10.1016/j.energy.2020.116894.

18. M. G. Bull, Development of an ammonia-burning gas turbine engine, Solar Turbines International, San Diego, CA, 1968.

19. J. Zhao, X. Mei, H. Yuan, G. Yu, N. Mei, Combustion characteristic of coal-ammonia composite, Energ. Source. Part A. 39(2017) 345-351, doi: https://doi.org/10.1080/15567036 .2016 .1214638 .

20. W. I. F. David, Ammonia: zero-carbon fertiliser, fuel and energy store, Policy Briefing, The Royal Society, London, 2020, url: https://royalsociety.org/-/media/policy/projects/ green-ammonia/green-ammonia-policy-briefing.pdf.

21. W. Zhou, B. Zhu, Q. Li, T. Ma, S. Hu, C. Griffy-Brown, $\mathrm{CO}_{2}$ emissions and mitigation potential in China's ammonia industry, Energ. Policy 38 (2010) 3701-3709, doi: https://doi. org/10.1016/j.enpol.2010.02.048.

22. S. Sircar, Production of hydrogen and ammonia synthesis gas by pressure swing adsorption, Sep. Sci. Technol. 25 (1990) 1087-1099, doi: https://doi. org/10.1080/01496399008051839.

23. C. Smith, A. K. Hill, L. Torrente-Murciano, Current and future role of Haber-Bosch ammonia in a carbon-free energy landscape, Energy Environ. Sci. 13 (2020) 331-344, doi: https:// doi.org/10.1039/C9EE02873K.

24. K. H. Rouwenhorst, A. G. Van der Ham, L. Lefferts, Beyond Haber-Bosch: The renaissance of the Claude process, Int. J. Hydrog. Energy 46 (2021) 21566-21579, doi: https://doi. org/10.1016/j.ijhydene.2021.04.014.

25. J. Armijo, J. C. Philibert, Flexible production of green hydrogen and ammonia from variable solar and wind energy: Case study of Chile and Argentina, Int. J. Hydrog. Energy 45 (2020) 1541-1558, doi: https://doi.org/10.1016/j. ijhydene.2019.11.028.

26. M. Wang, M. A. Khan, I. Mohsin, J. Wicks, A. H. Ip, K. Z. Sumon, C. T. Dinh, E. H. Sargent, I. D. Gates, M. G. Kibria, Can sustainable ammonia synthesis pathways compete with fossil-fuel based Haber-Bosch processes?, Energy Environ. Sci. 14 (2021) 2535-2548, doi: https://doi.org/10.1039/ D0EE03808C.

27. S. Giddey, S. P. S. Badwal, A. Kulkarni, Review of electrochemical ammonia production technologies and materials, Int. J. Hydrog. Energy 38 (2013) 14576-14594, doi: https:// doi.org/10.1016/j.ijhydene.2013.09.054.

28. S. Chaturvedi, P. N. Dave, Photocatalytic Hydrogen Production, Mater. Sci. Forum 764 (2013) 151-168, doi: https:// doi.org/10.4028/www.scientific.net/MSF.764.151.

29. K. Aasberg-Petersen, T. S. Christensen, C. S. Nielsen, I. Dybkjær, Recent developments in autothermal reforming and pre-reforming for synthesis gas production in GTL applications, Fuel Process. Technol. 83 (2003) 253-261, doi: 
https://doi.org/10.1016/S0378-3820(03)00073-0.

30. Y. Li, S. Hu, J. Chen, K. Müller, Y. Li, W. Fu, Z. Lin, H. Wang, Effects of biochar application in forest ecosystems on soil properties and greenhouse gas emissions: a review, J. Soil. Sedim. 18 (2018) 546-563, doi: https://doi.org/10.1007/ s11368-017-1906-y.

31. A. O. Gezerman, B. D. Corbacioglu, Influence of Expansion Valves on Gasification in Ammonia Storage Systems, Res. J. Chem. Sci. 2 (2012) 1-7.

32. A. Pearson, Refrigeration with ammonia, Int. J. Refrig. 31 (2008) 545-551, doi: https://doi.org/10.1016/j.ijrefrig.2007.11.011.

33. L. A. F. Domene, R. U. Ayres, Nitrogen's role in industrial systems, J. Ind. Ecol. 5 (2001) 77-103, doi: https://doi. org/10.1162/108819801753358517.

34. M. A. Shipman, M. D. Symes, Recent progress towards the electrosynthesis of ammonia from sustainable resources, Catal. Today 286 (2017) 57-68, doi: https://doi. org/10.1016/j.cattod.2016.05.008.

35. A. F. Bouwman, D. S. Lee, W. A. H. Asman, F. J. Dentener, K. W. Van Der Hoek, J. G. J. Olivier, A global high-resolution emission inventory for ammonia, Global Biogeochem. Cycle 11 (1997) 561-587, doi: https://doi.org/10.1029/97GB02266.

36. A. J. Hunt, E. H Sin, R. Marriott, J. H. Clark, Generation, capture, and utilization of industrial carbon dioxide, Chem. Sus. Chem. 3 (2010) 306-322, doi: https://doi.org/10.1002/ CSsc. 200900169

37. N. Zhou, D. Fridley, N. Z. Khanna, J. Ke, M. McNeil, M. Levine, China's energy and emissions outlook to 2050: Perspectives from bottom-up energy end-use model, Energy Policy 53 (2013) 51-62, doi: https://doi.org/10.1016/j.enpol.2012.09.065.

38. H. F. Johnstone, E. T. Houvouras, W. R. Schowalter, Low temperature catalytic oxidation of ammonia, Ind. Eng. Chem. Res. 46 (1954) 702-708, doi: https://doi.org/10.1021/ ie50532a031.

39. A. Valera-Medina, S. Morris, J. Runyon, D. G. Pugh, R Marsh, P. Beasley, T. Hughes, Ammonia, methane and hydrogen for gas turbines, Energy Proced. 75 (2015) 118-123, doi: https://doi.org/10.1016/j.egypro.2015.07.205.

40. G. B. Shul'pin, New trends in oxidative functionalization of carbon-hydrogen bonds: A review, Catalysts 6 (2016) 5090, doi: https://doi.org/10.3390/catal6040050.

41. P. Puri, F. Ma, J. Y. Choi, V. Yang, Ignition characteristics of cracked JP-7 fuel, Combust. Flame 142 (2005) 454-457, doi: doi:10.1016/j.combustflame.2005.06.001.
42. L. J. Christiansen, Ammonia: catalysis and manufacture, Springer Science \& Business Media, Berlin, 2012.

43. C. E. Amshel, M. H. Fealk, B. J. Phillips, D. M. Caruso, Anhydrous ammonia burns case report and review of the literature, Burns 26 (2000) 493-497, doi: https://doi.org/10.1016/ S0305-4179(99)00176-X.

44. R. T. Venterea, D. E. Rolston, Nitric and nitrous oxide emissions following fertilizer application to agricultural soil: Biotic and abiotic mechanisms and kinetics, J. Geophys. Res. Atm. 105 (2000) 15117-15129, doi: https://doi.org/10.1029/ 2000JD900025.

45. R. Lan, J. T. Irvine, S. Tao, Ammonia and related chemicals as potential indirect hydrogen storage materials, Int. J. Hydrog. Energy 37 (2012) 1482-1494, doi: https://doi.org/10.1016/j. ijhydene.2011.10.004.

46. C. C. Hale, W. H. Lichtenberg, U. S. anhydrous ammonia distribution system in transition, url: http://www.iffcokandla.in/data/polopoly fs/1.2500817.1438027709!/fileserver/ file/515325/filename/Aiche-28-012.pdf.

47. J. Brozda, Stress corrosion in ammonia storage-vessels and its prevention, Weld. Int. 9 (1995) 341-347, doi: https://doi. org/10.1080/09507119509548810.

48. A. Gladysiak, T. N. Nguyen, J. A. Navarro, M. J. Rosseinsky, K. C. Stylianou, A recyclable metal-organic framework as a dual detector and adsorbent for ammonia, Chem. Eur. J. 23 (2017) 13602-13606, doi: https://doi.org/10.1002/ chem. 201703510 .

49. S. H. Leghari, N. A. Wahocho, G. M. Laghari, A. H. Laghari, G. M. Bhabhan, K. H. Talpur, Role of nitrogen for plant growth and development: A review, Adv. Environ. Biol. 10 (2016) 209-218.

50. C. J. Dawson, J. Hilton, Fertiliser availability in a resource-limited world: Production and recycling of nitrogen and phosphorus, Food Policy 36 (2011) S14-S22, doi: https://doi. org/10.1016/j.foodpol.2010.11.012.

51. G. Evanylo, C. Sherony, J. Spargo, D. Starner, M. Brosius, $K$. Haering, Soil and water environmental effects of fertilizer-, manure-, and compost-based fertility practices in an organic vegetable cropping system, Agric. Ecosyst. Environ. 127 (2008) 50-58, doi: https://doi.org/10.1016/j. agee.2008.02.014

52. S. Giddey, S. P. S. Badwal, C. Munnings, M. Dolan, Ammonia as a renewable energy transportation media, ACS Sustain. Chem. Eng. 5 (2017) 10231-10239, doi: https://doi. org/10.1016/j.ijhydene.2020.01.145. 


\section{SAŽETAK \\ Kritička procjena tehnologija proizvodnje amonijaka i zelenog amonijaka \\ Ahmet Ozan Gezerman}

Emisije stakleničkih plinova do kojih dolazi tijekom industrijske proizvodnje sirovina znatno smanjuju kvalitetu zraka na globalnoj razini, što izravno utječe na kvalitetu života. S ciljem smanjenja emisija, države potiču razvijanje proizvodnih procesa koji su u skladu s propisima i zakonima. Industrijski proces koji trenutačno otpušta najveće količine ugljikova dioksida je sinteza amonijaka: čak 1,6 t ugljikova dioksida oslobađa se po toni proizvedenog amonijaka. S ciljem smanjenja emisije ugljika pri proizvodnji amonijaka, u ovom je radu napravljena procjenu procesa i tehnologije proizvodnje amonijaka te komentirana njihova održivost.

\section{Ključne riječi}

Zeleni amonijak, plavi amonijak, smeđi amonijak, vodik, emisija ugljika

Toros Agri \& Industry, Research \&

Development Center,

Karaduvar M. 132. C. No: 3

33 020, Mersin, Turska
Pregledni rad

Prispjelo 10. ožujka 2021 Prihvaćeno 17. srpnja 2021. 